\title{
HUBUNGAN ANTARA DEMOKRASI DENGAN PEMBANGUNAN EKONOMI
}

Oleh :

Nurul Hikmah

\section{Pendahuluan}

Debat hubungan antara demokrasi dan pembangunan sudah berlangsung lama. Meskipun negara-negara barat memeluk liberal, tradisi politik pluralistik dan menikmati kemakmuran, namun dengan adanya kemiskinan di belahan dunia lainnya, dimanakah letak kebaikan dan bagusnya dari demokrasi. Bagi teoritis dan ahli lainya, negara dunia ketiga tidak dapat mengalami kemakmuran karena banyak negara yang masih otoritarian dengan monopoli politik dan ekonomi. Sekarang negara-negara dunia ketiga banyak mengikuti demokrasi guna perbaikan dalam pembangunan ekonominya. Terlepas dari kegagalan yang ada, makalah ini mencoba menjelaskan tentang hubungan demokrasi dengan pembangunan ekonomi. Sebelum menjelaskan lebih lanjut dapat dipahami apa yang dimaksud dengan demokrasi dan pembangunan ekonomi.

Demokrasi berbeda dengan demokratis. Demokrasi secara harfiah dapat dipahami dari asal usul katanya yaitu demos dan kratos. Istilah demokrasi mengacu pada sistem pemerintahan masa Yunani yang disebut dengan demokratia, berasal dari kata demos (rakyat) dan kratos (pemerintahan). Secara bebas, demokrasi dapat diterjemahkan sebagai pemerintahan yang dijalankan oleh rakyat. Kemudian masa Romawi, orang-orang lebih menyukai istilah republik untuk menyebut sistem pemerintahannya. Republik berasal dari kata res (peristiwa) dan publicus (publik), yang artinya kurang lebih sebagai sesuatu yang dimiliki oleh publik atau rakyat. Roberth A. Dahl, seorang pakar masalah demokrasi Amerika menyatakan bahwa antara demokrasi dan republik tidak ada perbedaan yang signifikan. $^{2}$

Dalam prakteknya, demokrasi dipahami dan dijalankan secara berbeda-beda. Praktek demokrasi di Yunani kurang lebih 500 tahun sebelum Masehi, yang diyakini sebagai pemerintahan demokratis pertama, dipahami sebagai pemerintahan yang dijalankan oleh seluruh warga kota yang berjenis kelamin laki-laki. Proses demokrasi berjalan ketika seluruh warga berkumpul dan membentuk suatu `majelis` untuk memilih beberapa pejabat penting dalam pemerintahan kota. Namun yang unik, beberapa jabatan publik diperebutkan oleh beberapa warga yang dianggap memenuhi syarat berdasarkan undian. Pada saat itu, di Yunani tidak dikenal dengan istilah negara dalam pengertian sekarang, namun yang ada adalah kota-kota independen yang memiliki sistem pemerintahannya sendiri. Masingmasing kota, walaupun secara geografis berdekatan,

\footnotetext{
${ }^{2}$ Demoskratos=Demokrasi: Panduan Bagi Pemula, 2003. Jakarta: The RIDEP INSTITUTE, hlm. 1.
} 
tetapi tidak saling berhubungan, kecuali dalam pertahanan mereka membentuk lembaga perwakilan yang disebut liga atau konfederasi. ${ }^{3}$

Kemudian, pada masa Romawi, semula hak untuk turut serta dalam pemerintahan hanya terbatas pada patricia, yaitu kaum aristokrat atau kaum bangsawan. Namun, perkembangan selanjutnya menunjukkan bahwa rakyat berhasil memperoleh hak untuk terlibat dalam pemerintahan. Tentu saja, hak ini diperoleh setelah rakyat berjuang dengan keras. 4

Ini berbeda dengan praktek demokrasi yang dijalankan pada jaman modern abad 20, perbedaannya adalah sistem pemerintahan perwakilan telah dipraktekan. Pada mana terkadang semua warga negara, laki-laki dan perempuan yang dianggap memenuhi syarat berhak dipilih dan memilih wakilnya di pemerintahan dan parlemen, yang dilakukan secara demokratis. Alasan mengapa diperlukan mekanisme perwakilan adalah karena pertimbangan efisiensi, yaitu karena banyaknya jumlah penduduk dan luasnya jangkauan wilayah geografis yang tidak mudah dijangkau. ${ }^{5}$

Lalu bagaimana dengan demokratis? Demokratis diartikan sebagai proses demokrasi. Bila rakyat terlibat dalam pemilihan pemerintahan, atau rakyat turut serta dalam menentukan keputusan-keputusan yang diambilnya, maka pemerintahan itu bisa dianggap sebagai pemerintahan demokratis. Sebaliknya, jika semua itu ditentukan oleh pemerintah maka pemerintahan tidak demokratis. ${ }^{6}$ Dikenal pula istilah demokratisasi, istilah tersebut maknanya adalah proses demokrasi sebagaimana hal yang telah diuraikan diatas dan akan dijelaskan lebih lanjut kemudian.

Pada dasarnya, demokrasi adalah partisipasi seluruh rakyat dalam mengambil keputusan-keputusan politik dan menjalankan pemerintahan. Keputusan politik yang dimaksud adalah kesepakatan yang ditetapkan menjadi sebuah aturan yang akan mengatur kehidupan seluruh rakyat itu sendiri. Keterlibatan atau partisipasi rakyat adalah hal yang sangat mendasar dalam demokrasi, karena demokrasi bukan hanya berkaitan dengan tujuan sebuah ketetapan yang dihasilkan oleh suatu pemerintahan, tetapi juga berkaitan dengan seluruh proses dalam membuat ketetapan itu sendiri. Oleh karena itu, demokrasi mengandung elemen-elemen mendasar yang perlu diperhatikan dan dipahami. Elemnelemen itu adalah: ${ }^{7}$

1. Demokrasi mengakui kesetaraan setiap individu. Artinya, setiap orang (warga negara) memiliki kedudukan yang sama, tidak ada yang tinggi atau yang rendah.

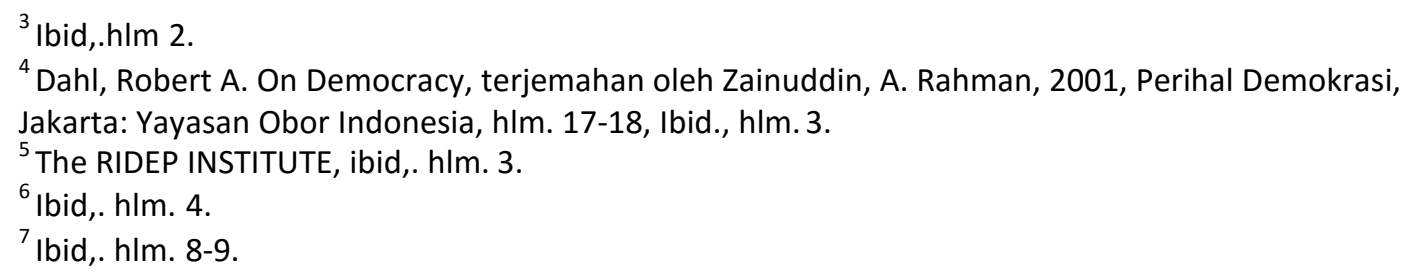


2. Nilai-nilai yang ada pada setiap individu mengatasi nilai-nilai yang ada pada demokrasi. Maknanya adalah demokrasi tidak merupakan wadah kosong, tetapi sangat ditentukan oleh nilai-nilai yang dianut oleh masyarakat.

3. Pemerintah bukanlah penguasa yang sesungguhnya, karena dalam demokrasi, pemerintah merupakan pelayan masyarakat, sebagai pemilik kedaulatan dan kekuasaan sejati.

4. Toleransi dari mayoritas kepada minoritas. Disini tercermin pula saling melindungi, saling menghargai dan yang besar mengayomi yang kecil.

5. Adanya musyawarah dalam memutuskan setiap persoalan, bukan ditentukan sendiri oleh kelompok mayoritas, karena akan berubah menjadi tirani mayoritas.

6. Adanya aturan hukum yang diterapkan untuk semuanya. Demokrasi tanpa aturan hukum akan menjadi anarkis. Karena itu, hukum merupakan dasar yang paling penting.

7. Adanya cara untuk mencapai tujuan bersama, apakah itu prosedur atau mekanisme maupun tata caranya. Semuanya harus mengikuti kaidah-kadiah demokrasi. demokrasi yang baik harus pula dilakukan dengan cara yang baik.

Menurut Thomas R. Dye dan Harmon Zeilgler ${ }^{8}$, ide dasar dari demokrasi merefleksikan empat hal:

1. Merupakan partisipasi rakyat di dalam keputusan yang membentuk kehidupan individu-individu dalam suatu masyarakat.

2. Merupakan pemerintahan yang dipimpin oleh mayoritas dengan pengakuan hakhak minoritas, yaitu hak kebebasan berbicara, berserikat, berkumpul, mendapatkan informasi, membentuk partai oposisi, dan menjalankan jabatan-jabatan publik.

3. Merupakan komitmen untuk menghargai martabat individu dan menjamin nilainilai kehidupan yaitu kebebasan dan kepemilikan.

4. Suatu komitmen untuk memberikan kesempatan yang sama bagi setiap orang untuk mengembang kemampuan dirinya.

Menurut P. Sharma 9 , inti dalam demokrasi ialah: suatu sistem atau suatu cara/ metode mengatur kekuasaan negara yang tidak mudah untuk disalahgunakan dalam pelaksanaannya, dimana garis besar daripada sistem tersebut ialah adanya pembagian dan pembatasan wewenang kekuasaan pada setiap pejabat penguasanya selaku penguasa negara, dengan mengadakan pembagian kekuasaan negara atas beberapa bidang

\footnotetext{
${ }^{8}$ Menurut Thomas R. Dye dan Harmon Zeilgler, The Irony of Democracy Uncommon Introduction to American Politic, (California: Wardsworth Publishing Company, 1996), hlm. 7., ibid.hlm.10.

${ }^{9}$ P. Sharma, 2004. Sistem Demokrasi yang Hakiki, Jakarta: Yayasan Menara IImu., hlm. 217.
} 
kekuasaan, guna mencegah adanya dominasi atau monopoli kekuasaan yang dapat membuat pejabat penguasanya itu berubah menjadi absolut dan kemudian bersikap otoriter, karena sistem kekuasaan absolutlah yang merupakan sistem kekuasaan negara yang mudah kemungkinannya bagi para pejabat penguasanya untuk melakukan penyalahgunaan jabatan seperti korupsi, manipulasi, kolusi, dan nepotisme, serta untuk bertindak zhalim terhadap masyarakat/rakyat.

Hakekat yang terkandung di dalam sistem demokrasi ialah: dengan dapat dicegah terjadinya kezhaliman, kecurangan, korupsi, dan manipulasi yang mungkin dapat dibuat oleh para pejabat penguasanya, maka hal tersebut pada gilirannya juga akan bisa menjadikan terlaksana dan terbinanya pemerintahan yang adil dan bijaksana. Dan adanya keadilan yang hakiki ini adalah merupakan kondisi yang mutlak dibutuhkan bagi setiap negara sebagai persyaratan untuk dapat terwujudnya kesejahteraan bagi seluruh rakyatnya. $^{10}$

Prinsip-prinsip demokrasi menurut P. Sharma: ${ }^{11}$

1. Kekuasaan Negara harus di tangan rakyat.

2. Pelaksanaan kekuasaan negara harus terbagi dan terbatas dalam beberapa badan/ bidang kekuasaan yang saling berbeda fungsinya, dengan semua kepala (pejabat tertingginya) adalah sama tinggi kedudukannya.

3. Tidak boleh ada hak istimewa pada seseorang atau pada suatu golongan/partai.(pemberian hak istimewa ditetapkan didalam undang-undang dasar).

4. Harus ada Undang-Undang Dasar Negara dan undang-undang HAM.

5. Rakyat harus berpendidikan cukup.

Menurut peneliti demokrasi Amerika Roberth Dahl ${ }^{12}$ menyebutkan dua dimensi dasar demokrasi yang saling berkaitan. Pertama, harus tersedianya ruang persaingan terbuka untuk mendapatkan semua kedudukan dan kekuasaan politik. Kedua, pada saat yang bersamaan harus tersedianya juga ruang aktifitas yang cukup dengan jaminan yang memadai bagi partisipasi politik seluruh warga negara. Intinya demokrasi adalah pemilihan yang bersifat umum, bebas, dan setara. Untuk melembagakan demokrasi yang dimaksud, Dahl memberikan beberapa kriteria sebagai prasyarat:

1. Kebebasan berasosiasi dan berkoalisi.

2. Hak untuk mengemukakan pendapat secara bebas.

3. Hak untuk memilih (hak pilih aktif).

\footnotetext{
${ }^{10}$ Ibid., hlm. 217.

${ }^{11}$ Ibid., hlm. 221.

${ }^{12}$ Merkel, Wolfgang, Demokrasi di Asia: Sebuah Benua antara Diktator dan Demokrasi, bahan kuliah Politik Ekonomi Demokrasi,MIS, UNPAR, 2009. hlm. 19-20.
} 
4. Hak untuk dipilih dalam satu jabatan publik (hak pilih pasif).

5. Hak politik elit, dalam bersaing untuk mendapatkan suara dan dukungan dari pemilih.

6. Adanya alternatif dan keberagaman sumber informasi (kebebasan informasi).

7. Pemilihan yang bebas dan adil.

8. Keberadaan Institusi, yang memungkinkan kebijakan pemerintah tergantung pada suara pemilih dan tuntutan preferensi publik.

Dalam demokratisasi yang dijelaskan pada makalah ini dikenal dua tahap, yaitu tahap transisi dan tahap konsolidasi. Transisi seperti dikatakan oleh O`Donnell dan Schmitter (1991) adalah masa antara dua rezim politik. Transisi demokrasi dimulai sejak bergulirnya proses desolusi (tumbangnya) sebuah rezim otoriter pada ujung yang satu dan ditegakkannya rezim demokrasi pada ujung yang lainnya. Pada tahapan ini penekanan ada pada penegakan demokrasi secara prosedural yakni berfungsinya berbagai institusiinstitusi politik secara demokratis. ${ }^{13}$

Namun untuk benar-benar menjadi negara demokrasi, haruslah dilalui tahap konsolidasi yang menurut berbagai literatur merupakan konsep yang tidak kalah sulitnya dibanding proses transisi. Bahkan banyak negara yang jatuh kembali ke rezim otoriter karena gagal menyelesaikan proses konsolidasi demokrasi (lihat Huntington 1991, Diamond 1997). Menurut Linz dan Stepan (1996), konsolidasi demokrasi berarti bahwa demokrasi bukan hanya telah tegak sebagai sebuah sistem politik tetapi juga telah membudaya di kalangan masyarakat. Bahkan betapapun besarnya tantangan dan kesulitan yang dihadapi masyarakat tidak akan berpaling dari demokrasi ke sistem politik lain. ${ }^{14}$

Tahap konsolidasi menghendaki perhatian pada segi-segi substantif. Karena di benak kebanyakan rakyat yang telah lama mengalami penindasan, ketidakadilan dan kemiskinan, demokrasi melambangkan lebih dari sekadar penghapusan institusi-institusi politik yang represif dan penggantian pemimpin-pemimpin otoriter. Demokrasi merepresentasikan kesempatan dan sumberdaya bagi perbaikan kualitas hidup serta bagi kehidupan sosial yang lebih adil dan manusiawi. Oleh karena itu, konsolidasi demokrasi

\footnotetext{
${ }^{13}$ O’Donnell, Guillermo, and Phillippe C. Schmitter. 1986. Transitions from Authoritarian Rule: Tentative Conclusions about Uncertain Democracies. Baltimore and London: The Johns Hopkins University Press. Ginandjar Kartasasmita, Strategi Pembangunan Ekonomi: Antara Pertumbuhan dan Demokrasi, Orasi Ilmiah Dalam Acara Wisuda Sarjana Sekolah Tinggi Ilmu Ekonomi (STIE) Ahmad Dahlan Jakarta 26 April 2008, hlm. 3-4.

${ }^{14}$ Huntington, Samuel P. The Third Wave: Democratization in the late twentieth century. Norman, University Of Oklahoma Press, 1991. Diamond, Larry and Marc F.Plattner. Economic Reform and Democracy; ed.by Larry Diamond. baltimore, John Hopkins, 1995. Linz, Juan J., and Alfred Stepan. Problems of Democratic Transition and Consolidation: Southern Europe, South America and PostCommunist Europe. Baltimore and London: The Johns Hopkins University Press. 1996. ibid,. hlm.4.
} 
harus menjamin terwujudnya esensi demokrasi: pemberdayaan rakyat (popular empowerment) dan pertanggungjawaban sistemik (systemic responsiveness). ${ }^{15}$

Pembahasan mengenai masalah demokrasi ini tidak pernah berhenti karena dari sejarah, terutama belakangan ini, tampak makin jelas betapa erat kaitan antara kemajuan kehidupan umat manusia dan demokrasi. Namun, tali-temali kaitan itu dalam kehidupan ekonomi dan politik tidak selalu mudah dipahami. Pengalaman menunjukkan betapa demokrasi dipertentangkan dengan stabilitas dan kemajuan ekonomi pada tahun-tahun awal setelah Perang Dunia II. Betapa banyak pemikiran di negara berkembang mengarah kepada perlunya pemerintah yang "kuat" (baca: tidak perlu demokratis), untuk menjamin stabilitas dan membawa kemajuan. Pemikiran tersebut menganggap demokrasi, sebagai sistem dan manifestasi budaya politik Barat, hanya akan mendatangkan "chaos" dan tidak menunjang pembangunan.

Namun, perkembangan sejarah menunjukkan sebaliknya, pertumbuhan yang terjadi tanpa demokrasi tidak mampu berjalan secara berkelanjutan seperti dibuktikan oleh pengalaman negara-negara komunis. Pertumbuhan ekonomi dalam sistem yang tidak mengindahkan partisipasi politik rakyat cenderung menghasilkan kesenjangan, yakni kesenjangan antara yang memperoleh kesempatan dan tidak memperoleh kesempatan dalam sistem yang tertutup. Seperti dikatakan Axworthy (2000) \|To thrive, democracy requires growth; and to grow economies need democracy". 16

Menurut Lincolin Arsyad ${ }^{17}$ pembangunan ekonomi mempunyai pengertian yaitu:

- Suatu proses yang berarti perubahan yang terjadi terus menerus

- Usaha untuk menaikan pendapatan per kapita, dan kenaikan yang berlangsung dalam jangka panjang.

- Perbaikan sistem kelembagaan di segala bidang ekonomi, politik, hukum, sosial, dan budaya. Baik secara institusi maupun secara regulasi.

Negara-negara industri baru yang sukses dalam pembangunan ekonomi ternyata adalah negara-negara yang menerapkan asas-asas demokrasi. Di Asia dan Amerika Selatan demokrasi dan kesejahteraan berjalan bergandengan. Menerapkan demokrasi memang tidak secara otomatis akan memajukan ekonomi. Seperti yang terjadi di India, ekonomi India tidak segera berkembang sampai kemudian negara tersebut menggulirkan kebijaksanaankebijaksanaan pembaharuan dan membuka perekonomiannya hingga kini India mulai dipertimbangkan menjadi kekuatan ekonomi dunia yang besar. Dengan

\footnotetext{
${ }^{15}$ ibid,. hlm. 4.

${ }^{16}$ Axworthy, Thomas S. 2000, Towards a just Society the Trudeau Years. Toronto: Penguin Books. ibid,. hlm. 3.

${ }^{17}$ Arsyad, Lincolin. 1999, Pengantar Perencanaan dan Pembangunan Ekonomi Daerah. Yogyakarta: BPFE-Yogyakarta,. hlm. 6.
} 
demikian, demokrasi akan membawa kemajuan ekonomi bila memang ditunjang dengan kebijakan-kebijakan ekonomi yang tepat.

Keterkaitan antara demokrasi dengan kesejahteraan masyarakat melalui ekonomi pasar telah sedemikian berkembang dan teruji selama lebih dari dua ratus tahun di negaranegara Barat. Sedemikian erat keterkaitan kedua hal tersebut sehingga dalam perkembangannya peningkatan kesejahteraan rakyat juga telah dijadikan barometer berlangsung tidaknya proses demokrasi. Artinya, proses demokrasi belum dapat dikatakan baik bila tidak dapat melahirkan peningkatan kesejahteraan. Seorang ekonom penerima nobel Amartya Sen (2001) melukiskan demokrasi sebagai koridor utama dalam memahami persoalan kemiskinan. Pandangan Amartya Sen telah menginspirasi banyak pemikiran tentang bagaimana memahami miskin(buruk)nya demokrasi yang melahirkan ketidakadilan. Sebabnya antara lain karena terbatasnya kesempatan dan suara masyarakat miskin dalam menyampaikan aspirasinya, yang bisa berakibat terdilusinya sasaran banyak program-program pembangunan ekonomi. ${ }^{18}$

Dalam pembangunan ekonomi yang diupayakan untuk dapat terwujud tentunya kesejahteraan dan kemakmuran yang adil dan merata. Konsep kemakmuran dipahami dalam kaitan dengan keperluan manusia akan barang-barang yang berguna bagi hidup dan usaha manusia untuk mempertahankan hidupnya. Hidup manusia disebut — makmur\|kalau barang-barang yang perlu dan berguna bagi manusia tersedia dengan cukup atau bahkan dengan berlimpah-limpah. ${ }^{19}$

\section{Demokrasi dan Pembangunan Ekonomi}

Setelah memahami demokrasi dan inti dari pembangunan ekonomi maka didapatkan bahwa demokrasi seharusnya berjalan seiringan dengan pembangunan ekonomi (kesejahteraan dan kemakmuran). Ditahun 1959, Martin Seymor Lipset membuat sebuah hipotesis yang sampai sekarang tidak terbantahkan yaitu negara-negara yang kaya umumnya adalah demokratis dan negara-negara yang demokratis umumnya kaya. Samuel Huntington (1996) mengadakan penelitian bahwa dengan pendapatan per kapita antara \$1000 sampai \$3000, negara yang menganut paham otoriter akan memasuki zona transisi menuju proses demokrasi. Hal ini diperkuat oleh banyak peneliti dan pakar lain seperti Adam Przeworski (2000) dan Fareed Zakaria (2003). ${ }^{20}$

\footnotetext{
${ }^{18}$ Sen, Amartya. 2001, Democracy as a Universal Value. In L. Diamond et al., editors. The Global Divergence of Democracies. Baltimore, Maryland: The Johns Hopkins University Press. op.cit,. hlm. 5.

${ }^{19}$ Sindhunata. 2000, Sakitnya Melahirkan Demokrasi, Yogyakarta: Penerbit Kanisius,. hlm. 200.

${ }^{20}$ Ginandjar Kartasasmita, Strategi Pembangunan Ekonomi: Antara Pertumbuhan dan Demokrasi, Orasi Ilmiah Dalam Acara Wisuda Sarjana Sekolah Tinggi Ilmu Ekonomi (STIE) Ahmad Dahlan Jakarta 26 April 2008,. hlm. 8-9.
} 
Secara empiris telah jelas dibuktikan bahwa ada korelasi yang erat antara sistem politik yang ditempuh dengan tingkat kemajuan ekonomi. Memang ada perkecualian seperti Sri Lanka yang sistem politiknya adalah demokrasi, tetapi ekonominya mandeng. Tetapi hal tersebut disebabkan karena konflik-konflik internalnya. Demikian juga India, seperti telah dicontohkan di atas, sebagai negara demokrasi — tertuall di Asia dan yang paling bertahan di negara-negara yang baru merdeka sejak Perang Dunia II, yang untuk jangka waktu yang lama ekonominya stagnan. Tetapi banyak pengamat menilai bukan karena demokrasinya, tetapi problem sosialnya yang sangat tajam seperti konflik etnik dan masalah kasta. Meskipun dengan menghadapi masalah-masalah yang demikian mendasar, baik struktural maupun kultural, India belakangan ini telah mulai tumbuh maju secara ekonomi, yang menafikan skeptisme terhadap demokrasi di luar dunia barat. Kita melihat Turki, yang demokrasinya jatuh bangun, tetapi belakangan ini telah lebih mantap meskipun di — jagall oleh kekuatan militer yang sangat sekuler secara ketat, ekonominya telah bergerak maju, dan sebagai produknya, tumbuh kaum kelas menengah muslim, yang akhirnya melahirkan kemenangan politik bagi partai politik yang bernafaskan Islam.

Dari berbagai uraian itu ada beberapa pelajaran yang dapat ambil, yaitu:

1. Demokrasi bila prasyarat untuk menjalankannya dipenuhi, adalah sistem yang sudah terbukti bertahan selama ratusan tahun.

2. Semua sistem lawannya telah tumbang satu-persatu (monarki absolut, fasisme, komunisme).

3. Demokrasi berpotensi dapat menghasilkan kesejahteraan karena hak-hak politik dan sipil anggota masyarakat yang terlindungi, dan dengan demikian juga kreativitas dan inovasinya.

Apabila demokrasi tidak menghasilkan kemajuan dan perbaikan kesejahteraan, ada dua kemungkinan penyebabnya:

1. Demokrasi yang dijalankan tidak benar, dalam arti tidak sesuai dengan prinsip-prinsip dasar demokrasi.

2. Kebijakan-kebijakan publik yang dijalankan tidak ditujukan untuk menghasilkan perbaikan kesejahteraan. Demokrasi hanyalah sebuah sistem politik, maka untuk menghasilkan kemajuan sosial ekonomi perlu diikuti oleh kebijakan-kebijakan publik yang ditujukan untuk kemajuan sosial ekonomi.

Pembangunan ekonomi memang mengharapkan terciptanya kemakmuran. Namun, kemakmuran bisa dipahami secara berbeda oleh setiap individu. Hal ini terjadi karena dalam proses menuju makmur, manusia tidak hidup sendiri-sendiri tetapi hidup bersama dalam masyarakat. Maka, ketersediaan barang bagi manusia perlu ditata dan dijamin melalui aturan hak milik. Demokrasi menjamin adanya pengaturan hak milik, hal ini 
dimaksudkan agar tidak terjadi jurang perbedaan yang dalam antara orang yang kaya dengan yang miskin juga timbulnya sikap toleran persoalan hak milik, supaya orang yang punya milik banyak tidak memperbudak yang kurang memiliki.

Mengingat barang dan jasa jumlahnya terbatas juga harus diproduksi, maka demokrasi meniadakan hak istimewa kepada seseorang/kelompok/golongan bahkan negara. Hal ini dimaksudkan agar tidak terjadi monopoli bagi yang memproduksi sehingga barang dan jasa tidak dijual dengan harga yang setinggi-tingginya. Menurut P.Sharma, ${ }^{21}$ didalam sistem demokrasi tidak boleh ada monopoli usaha, baik oleh perseorangan, golongan, maupun oleh negara. Demikian pula tidak boleh ada kaum kapitalis yang memiliki harta yang sebanyak-banyaknya tanpa batas, dan kaum feodal yang bisa memiliki lahan tanah seluas-luasnya. Dengan kata lain, di dalam negara demokrasi harus dicegah adanya kapitalisme dan feodalisme.

Dalam pembangunan ekonomi, khususnya menyangkut mekanisme pasar (sistem ekonomi) maka suatu negara sekarang ini dihadapkan pada pilihan sistem kapitalis murni, negara tidak mengintervensi market, karna sudah di atur oleh invisible hand atau memilih sistem ekonomi campuran dimana negara berperan dalam pengambilan keputusan dan kebijakan dalam mekanisme pasar. Dalam demokrasi perekonomian dilaksanakan melalui kebijaksanaan ekonomi yang berazaskan prinsip mekanisme pasar yang mengacu pada pertumbuhan, pemerataan, dan stabilitas. Selanjutnya, mekanisme pasar yang berlaku juga harus mampu mencegah timbulnya persaingan bebas dan pemusatan kekuatan ekonomi yang menjurus ke arah konglomerasi dan berbagai bentuk monopoli yang merugikan masyarakat. Dalam hal ini pemerintah berfungsi mengayomi, bukan menguasai bagi kepentingan golongan yang berkuasa. Diharapkan tercipta mekanisme pasar yang adil, dinamis, dan transparan, sekaligus juga kesenjangan struktural, sektoral maupun sosial akan dapat ditekan sampai tingkat paling rendah. ${ }^{22}$ Dengan demikian demokrasi menghindari tiga hal berikut:

1. Sistem free fight liberalism yang menumbuhkan eksploitasi.

2. Sistem etatisme dimana negara beserta aparatur ekonominya bersifat dominan.

3. Pemusatan kekuatan ekonomi pada satu kelompok.

Adanya aturan hukum yang jelas dan kepastian serta ketaatan pemerintah terhadap hukum sangat mempengaruhi pembangunan ekonomi. Demokrasi tanpa hukum akan menjadi anarkis,sehingga hukum menjadi salah satu dasar yang penting. Setiap ada

\footnotetext{
${ }^{21}$ P. Sharma, 2004. loc.cit,. hlm. 242.

${ }^{22}$ Seminar sehari yang diselenggarakan oleh DPP-IP-KI (Dewan Pengurus Pusat - Ikatan Pendukung Kemerdekaan Indonesia) bekerjasama dengan LEMHANAS pada 17 Desember 1996 dalam membahas buku “Demokrasi Ekonomi”terbitan IPKI-LEMHANAS.
} 
tindakan pemerintah yang cenderung menjauhi aturan dan kepastian hukum, dipastikan respon pertumbuhan ekonomi akan memburuk. ${ }^{23}$

\section{Kesimpulan}

Dapat disimpulkan, bila demokrasi tidak disertai oleh tatanan politik dan aturan politik serta hukum yang jelas, suatu kondisi tertentu bisa berubah menjadi anarkisme dan bahkan kemudian mengundang otoriterianisme yaitu suatu pemerintahan yang menindas dan berlawanan dengan prinsip demokrasi. Karena itu, kalau demokrasi mau konsisten maka konstitusi perlu mengatur semua tatanan itu.

Dalam konteks kekuasaan politik, diperlukan persamaan kesempatan dalam mengambil keputusan bagi seluruh orang untuk terlibat di dalamnya. Dalam setiap sistem masyarakat selalu ada pihak yang memerintah dan pihak yang diperintah. Pihak yang memerintah biasanya disebut elit dan secara kuantitas selalu lebih sedikit dari pihak yang diperintah. Sementara pihak yang diperintah biasanya disebut dengan rakyat atau warga atau masyarakat atau massa. Diperlukan suatu mekanisme kontrol agar kekuasaan elit ini tidak disalahgunakan sehingga tidak merugikan pihak mayoritas yang diperintah.

Dalam On Democracy, Robert A. Dahl ${ }^{24}$ telah merumuskan dengan baik mengapa sistem demokrasi lebih baik dari sistem yang lain terhadap ekonomi pembangunan:

1. Demokrasi dapat mencegah tumbuhnya pemerintahan otokrat yang kejam dan licik.

2. Demokrasi menjamin hak asasi manusia.

3. Demokrasi menjamin kebebasan pribadi yang lebih luas dari rakyatnya.

4. Demokrasi membantu rakyat untuk melindungi kepentingan dasarnya.

5. Demokrasi memberikan kesempatan yang sebesar-besarnya bagi rakyat untuk menggunakan kebebasan menentukan nasibnya sendiri, yaitu hidup di bawah hukum yang mereka pilih sendiri.

6. Demokrasi dapat memberikan kesempatan sebesar-besarnya untuk menjalankan tanggung jawab moral.

7. Demokrasi membantu perkembangan kapasitas manusia lebih besar dari sistem yang lain.

8. Demokrasi menjamin perkembangan tingkat persamaan politik yang lebih tinggi.

9. Terdapat kecenderungan bahwa antar sesama negara demokratis tidak saling berperang.

\footnotetext{
${ }^{23}$ Ahmad Erani Yustika, Demokrasi Prasyarat Ekonomi, rubrik opini KOMPAS, 15 September 2004.

${ }^{24}$ Dahl, Robert A. On Democracy, terjemahan oleh Zainuddin, A. Rahman, 2001, Perihal Demokrasi, Jakarta: Yayasan Obor Indonesia, hlm. 83-85,. Loc. Cit,. hlm. 45-46.
} 
10. Negara yang demokratis cenderung lebih makmur daripada sistem-sistem pemerintahan yang lain.

Memang terkadang muncul dilema, terutama negara-negara yang kondisi perekonomiannya kurang. Terkadang ketetapan yang dihasilkan oleh suatu pemerintahan yang sewenang-wenang tidak lebih buruk dari ketetapan yang dihasilkan oleh suatu pemerintahan yang demokratis. Namun, hal itu tidak berarti bahwa pemerintahan yang sewenang-wenang lebih baik. Karena argumentasi bahwa keterlibatan rakyat lebih penting karena hal ini berkaitan dengan martabat individu. Kebajikan terbaik dari manusia adalah jika eksistensi kehidupannya, kebebasannya, dan hak kepemilikannya dijamin oleh hukum. Secara moral, kebebasan dan hak kepemilikan adalah hukum alam, dan jaminan akan kebebasan inilah yang sesungguhnya hendak dijamin dalam sistem pemerintahan demokrasi.

Masalah dalam pembangunan sangatlah kompleks salah satunya masalah kemiskinan, dimana kesejahteraan dan kemakmuran belum tercapai secara adil dan merata. Kaitannya, demokrasi berkaitan dengan kepercayaan rakyat terhadap pemerintahan yang berkuasa, diperlukan legitimasi dari rakyat agar pemerintahan tersebut demokratis. Untuk itu pula diperlukan suatu sistem yang dapat meyakinkan rakyat bahwa semua hak-haknya akan dijamin.

Hak tersebut adalah hak untuk memiliki kesempatan yang sama (equality of opportunity), yang meliputi persamaan sosial, politik, ekonomi, pendidikan dan kesamaan di depan hukum. Satu-satunya sistem yang mampu meyakinkan bahwa rakyatnya memiliki kesempatan sama adalah demokrasi, meskipun mereka adalah miskin, atau penganut agama yang tidak populer, atau dari etnis minoritas, atau berasal dari kampung.

\section{Daftar Pustaka}

\section{Buku}

Arsyad, Lincolin. 1999, Pengantar Perencanaan dan Pembangunan Ekonomi

Daerah. Yogyakarta:BPFE-Yogyakarta

Demoskratos=Demokrasi: Panduan Bagi Pemula, 2003. Jakarta: The RIDEP INSTITUTE.

Merkel, Wolfgang, Demokrasi di Asia: Sebuah Benua antara Diktator dan Demokrasi, bahan kuliah Politik Ekonomi Demokrasi,MIS, UNPAR, 2009.

P. Sharma, 2004. Sistem Demokrasi yang Hakiki, Jakarta: Yayasan Menara Ilmu.

Sindhunata. 2000, Sakitnya Melahirkan Demokrasi, Yogyakarta: Penerbit Kanisius. 


\section{File PDF}

Ginandjar Kartasasmita, Strategi Pembangunan Ekonomi: Antara Pertumbuhan dan Demokrasi, Orasi Ilmiah Dalam Acara Wisuda Sarjana Sekolah Tinggi Ilmu Ekonomi (STIE) Ahmad Dahlan Jakarta 26 April 2008.

Seminar sehari yang diselenggarakan oleh DPP-IP-KI (Dewan Pengurus Pusat - Ikatan Pendukung Kemerdekaan Indonesia) bekerjasama dengan LEMHANAS pada 17 Desember 1996 dalam membahas buku -Demokrasi Ekonomillterbitan IPKILEMHANAS.

\section{Artikel Koran}

Ahmad Erani Yustika, Demokrasi Prasyarat Ekonomi, rubrik opini KOMPAS, 15 September 2004. 